der/umuligheder er udtryk for et holistisk træk ved dette område og ikke en individuel egenskab. Det betyder så også, at vi i vores forståelse af entiteternes modalitet forpligter os på mere end der kan udtrykkes eksplicit gennem lovmæssigheder, fordi, som Rouse hævder $\mathrm{i}$ indledningen "Even in those scientific fields in which the explicit articulation of laws has been of central concern, there is arguably no example of an extensionally complete set of laws for a domain" (p. xv). Samtidig har forpligtelsen betydning ikke kun for de forskellige områder plus tilhørende entiteter vi er engageret i, men også for vores eget liv og muligheder. Så Dasein er, som living a way of life, udtryk for en modal forståelse af væren, der forsøger at lade forskellige muligheder, for tingene og sig selv, være til. Så, med Haugelands Heidegger har vi fået en ny forståelse af modalitet, en eksistential modalitet.

Med Having Thought og nu Dasein Disclosed er konturerne af en reflekteret, velartikuleret og sofistikeret filosofisk position lagt fremsom for fremtiden sandsynligvis vil blive en inspirationskilde for en række temaer på tværs af den analytiske og kontinentale filosofi, og måske rippe lidt op i meget af den eksegetiske Heideggerforskning.

Bo Allesoe Christensen

\title{
Levende lærer af de døde - retsmedicinens udvikling i de vestlige samfund
}

Katherine D. Watson:

Forensic Medicine in Western Society. A History, Routledge, 2011 , 214 sider, 32,95 USD.

Eftersom retsmedicinen omfatter medicinens anvendelse i retsvæsenets tjeneste, befinder den sig i et interessant krydsfelt mellem to af det moderne samfunds mest betydningsfulde vidensområder og institutioner. Samtidig danner det retsmedicinske videns- og praksisfelt et fascinerende sammenrendspunkt for en række af vor tids 
mest fundamentale eksistenserfaringer: Døden, kroppen, friheden, mordet, volden og kriminaliteten. De fleste af os kender da også både retsmedicinen fra nyhedsmedier samt utallige film, tv-serier og skønlitterære bøger i thriller- og krimigenren. I de senere år har disciplinen ikke mindst fået en øget offentlig eksponering, der skyldes implementeringen af en række nye laboratorieteknikker. Det har resulteret $i$ en ny metodologisk præcision i forhold til at kunne opklare nuværende kriminalsager og revurdere konklusioner fra tidligere efterforskninger. For eksempel så vi i 2011, hvordan det danske politi genåbnede 17 uopklarede drabssager for at undersøge bevismateriale med den forbedrede teknologi til analyse af DNAspor. Herunder en dengang 26 år gammel sag fra 1985, hvor 80årige Erna Larsen blev dræbt i Københavns nordvestkvarter.

Alligevel er retsmedicinens internationale idé- og institutionshistorie forholdsvist underbelyst. Den britiske medicinhistoriker Katherine D. Watson fra Oxford Brookes University råder bod på dette forhold med udgivelsen af Forensic Medicine in Western Society. A History. Watson har tidligere skrevet historiske bøger om bl.a. vold og giftmord, og det nye værk lægger sig fint i kølvandet heraf. Som titlen indikerer, anlægger værket et internationalt komparativt perspektiv på retsmedicinens historie gennem en afdækning af udviklingen af det dynamiske forhold mellem ret, medicin og samfund.

Watsons værk er struktureret omkring seks temaer inden for en overordnet kronologisk ramme, der underbygger en forståelse af, hvordan medicinen har spillet en rolle for retslig, politisk og social forandring i vesten. Som Watson i første omgang gør rede for, har den moderne retsmedicin en kontinentaleuropæisk oprindelse. De første egentlige værker om emnet blev udgivet af henholdsvis franskmanden Ambroise Paré i 1575 og italieneren Fortunatus Fidelis i 1598. At disciplinen opstår på kontinentet har ifølge Watson en retshistorisk baggrund. Nemlig i den forskel der var på udviklingen af de to overordnede retssystemer fra middelalderen og frem, som fulgte efter romerrigets fald. Det angliske retssystem fra England og det tidligere britiske imperium har sin historiske baggrund $\mathrm{i}$ engelsk common law, der blev etableret i kølvandet på den normanniske invasion i 1066. Udbredelsen af common law var knyttet til et anklagende system, som lagde vægt på mundtlige øjenvidneudsagn 
og en udstrakt brug af lægjurier i form af nævninge. Det kontinentale retssystem har derimod sin historiske baggrund i en fusion af romerretten og den kanoniske kirkeret fra det 12. århundrede, som var knyttet til udviklingen af et inkvisitorisk system. Det system var styret af professionelle dommere, som direkte udspurgte vidner og vurderede flere forskellige typer af bevisinformation. Den praksis involverede ofte eksterne eksperter, som f.eks. læger, der kunne hjælpe med at stadfæste sandheden.

Ifølge Watson må undersøgelsen af retsmedicinens historie dernæst gribe fat i et særligt praksishistorisk perspektiv. Nemlig et, der afdækker, hvordan medicinsk viden overhovedet er blevet anvendt i retssammenhænge på en måde, som har udgjort et historisk afsæt for etableringen af en egentlig retsmedicinsk disciplin. Som disciplinens latinske navn, medicina forensis, indikerer, har retsmedicinen i den forbindelse en forhistorie, som strækker sig endnu længere tilbage end middelalderen. Ordet forensis er således afledt af ordet forum, som var de bypladser i antikkens romerrige, hvor de offentlige retshandlinger fandt sted. Både $i$ antikkens Athen og senere $i$ romerriget tildelte retssystemerne da også læger en særrolle som ekspertvidner i retshandlinger. Hermed blev grunden lagt til en anvendelse af den lægefaglige viden og praksis, der havde mere fokus på kropsskader end på sygdom og galskab. Denne anvendelse blev udvidet i middelalderen, hvor det i det 13. århundredes Italien blev almindeligt at bruge obduktioner til at klarlægge dødsårsagen i drabssager. I England blev der formelt indført et coronersystem i 1194, som havde til opgave at undersøge visse dødsfald for at afgøre, om årsagen var selvmord eller anden dødsmåde.

Retsmedicinens formål defineres sommetider ved ordsproget Hic locus est ubi mors gaudet succurrere vitae, hvilket let omskrevet betyder, at levende lærer af de døde. I dag har retsmedicinen stor betydning for opklaring og forfølgning af såkaldt personfarlig kriminalitet såsom drab, vold og voldtægt. Men helt indtil det 18. århundrede blev sandheden om den slags sager først og fremmest fundet gennem brug af informanter og tortur. I tredje kapitel bringer Watson os ind i den moderne epoke ved at kigge på, hvordan der dukker en ny opfattelse af eksperter og ekspertise op i det 17. og 18. århundrede, som får betydning for etableringen af den moderne retsme- 
dicin. Indtil da blev den lægefaglige person anerkendt som ekspertvidne i retssystemet på baggrund af sin personlige indsigt, der var baseret på direkte erfaringer. I kølvandet på professionaliseringen af lægefaget opstår der imidlertid en ny idé om det medicinske ekspertvidne. Nemlig et sådant, der har decideret specialistviden, og som derfor kan understøtte opklaringsarbejdet og aflægge vidneforklaring i retten ud fra en rent professionel vurdering.

Michel Foucault har påvist, at idéen om det farlige individ og den tilhørende etablering af retspsykiatrien er et moderne fænomen. I fjerde kapitel understreger Watson supplerende, at gale kriminelle allerede havde en veldefineret juridisk status i det 14. århundrede. Samtidig blev der allerede fra og med denne periode etableret separate faciliteter til afsondring af de pågældende mennesker af hensyn til offentlighedens ve og vel. I kølvandet på oplysningstiden blev strafferetten præget af humanistiske og utilitaristiske idéer, der havde fokus på menneskets rationalitet og frie vilje. Kriminalitet blev nu opfattet som et resultat af den frie viljes nederlag til menneskets dyriske drifter. For at kunne bestemme de mistænktes skyld måtte man derfor undersøge deres psykiske habitus, og hermed blev man på ny konfronteret med spørgsmålet om de gale kriminelle. På samme tid begyndte lægefaget at interessere sig for galskaben som behandlingsegnet sindssygdom. Dermed blev psykiatrien etableret, og den begyndte hurtigt at identificere og definere de farlige sindssyge som et særskilt problem. Som resultat af denne tosporede udvikling blev der skabt en ny kobling mellem medicin og ret, som udkrystalliserede sig i retspsykiatrien og særforhold i strafferetten. I femte kapitel følger Watson op på spørgsmålet om adfærd og bevidsthed med en afdækning af den måde, hvorpå socialt afvigende adfærd er blevet gjort til et medicinsk-juridisk problem i moderne tid. Retsmedicinen har således haft en stor betydning for den måde, hvorpå selvmord, spædbarnsdrab, impotens og seksuelle afvigelser er blevet medikaliseret som straffeegnede fænomener.

Watson afslutter sit aldeles glimrende og engagerede, men også lidt summariske, overblik over retsmedicinens udvikling i de vestlige samfund med en gennemgang af nogle træk fra det 20. århundrede: Diagnosticeringen af seksuelt misbrug af børn; udviklingen af laboratorieteknikker; teknikker til etablering af identitet og død- 
stidspunkt i drabssager; blodtypebestemmelser og DNA-teknologi; og gerningsmandsprofilering.

Anders Draby Sorensen

\section{Italiensk frihedsontologi i Schellings ånd}

Luigi Pareyson:

Person og eksistens (oversat fra italiensk og med efterskrift af Jens $V$. O. Nielsen), Aarbus Universitetsforlag, 2011 , 384 sider, $349,95 \mathrm{kr}$.

Den italienske eksistensfilosof og hermeneutiker Luigi Pareyson (1918-1991) regnes i sit hjemland for én af det 20. århundredes væsentligste filosoffer. Pareyson var lærer for så prominente tænkere som bl.a. Umberto Eco og Gianni Vattimo, og studerede selv under bl.a. selveste Karl Jaspers i Heidelberg. Det gælder i øvrigt - til de flestes formodentlige overraskelse - at Pareyson faktisk gav sit oprindelige bud på en moderne, filosofisk hermeneutik tidligere endnu end de to tænkere, der ellers opfattes som fortolkningsfilosofiens sædvanlige faderfigurer; nemlig Hans-Georg Gadamer og Paul Ricoeur.

På dansk forelå indtil for nylig oversættelser af en mindre del af Pareysons Æstetik - Formskabelsens teori (1954) (der vel at mærke omtales rosende i Gadamers Wabrheit und Methode) såvel som af hans temmelig komprimerede men også uhyre læseværdige afskedsforelæsning fra 1988, Fribedens filosofi, der tilmed er forsynet med et fint forord fra danske Søren Gosvig Olesens pen. Samme Gosvig arbejder efter sigende på en oversættelse af det omfattende og sene hovedværk, Ontologia della libertà, der udkom posthumt i 1995, og som en syg og følgelig stærkt svækket Pareyson møjsommeligt arbejdede på i de sidste par årtier af sit liv.

Selvom Pareysons sene mellemværende med en Schelling-inspireret frihedsontologi efter alt at dømme udgør forfatterskabets filosofiske kulmination, er det afgjort tiden og koncentrationen værd 